\section{Tadej Braček}

University of Maribor

Slovenia
2016, Vol. 13 (2), 35-49(246)

revije.ff.uni-lj.si/elope

doi: 10.4312/elope.13.2.35-49

UDC: 821.111.09-344Radcliffe A.

\title{
Reaction to Crisis in Gothic Romance: Radcliffe's The Castles of Atblin and Dunbayne
}

\author{
ABSTRACT
}

Gothic romances were primarily women's domain. This is proven by the fact that from the end of the eighteenth century to the beginning of the nineteenth century more than fifty female authors wrote Gothic romances. In the first part the paper depicts the emergence of romances, clarifies the notion of the Gothic and explains the theory of Gothic romances. The second part focuses on Ann Radcliffe's first novel, The Castles of Athlin and Dunbayne. This section analyses in what way men and women react to crises. It concludes that reactions are primarily based not on sex but on the benevolence and malevolence of literary characters. The former react with higher intensity on the physical level (passing out, becoming ill) and the latter react vehemently in emotional sense towards their rivals. The originality of the article lies in the systematic analysis of characters' responses to crisis and in the study of atypical features of this Gothic novel.

Keywords: Gothic romance; Ann Radcliffe; men; women; crisis; response; The Castles of Athlin and Dunbayne

\section{Odzivi na krize v gotski romanci: Gradova Atblin in Dunbayne avtorice Ann Ward Radcliffe}

\section{POVZETEK}

Gotske romance so bile povečini ženska domena. To dokazuje dejstvo, da je od konca osemnajstega do začetka devetnajstega stoletja gotske romance pisalo več kot petdeset avtoric. V prvem delu članek oriše pojav romanc, pojasni pojmovanje gotike in razloži teorijo gotskih romanc. Drugi del obravnava prvi roman Ann Radcliffe, in sicer Gradova Athlin and Dunbayne. V njem razišče, kako se na krize odzivajo moški in ženske, in ugotovi, da odziv v veliki meri ni odvisen od spola, temveč od dobronamernosti oz. zlobe literarnih likov. Prvi se bolj odzivajo z večjo intenziteto $\mathrm{v}$ fizičnem smislu (omedlevanje, obolevanje), slednji pa z burnim čustvenih reagiranjem, uperjenim proti rivalom. Originalnost članka leži v sistematični analizi odzivov literarnih protagonistov in antagonistov ter atipičnosti proučevanega gotskega romana.

Ključne besede: gotska romanca; Ann Radcliffe; moški; ženske; krize; odzivi; Gradova Athlin in Dunbayne 


\section{Reaction to Crisis in Gothic Romance: Radcliffe's The Castles of Athlin and Dunbayne}

\section{Introduction}

Ann Ward Radcliffe was a masterful, model eighteenth-century Gothic writer. Her novels swing between the irrational fear and real dangers that threaten the heroes and heroines. They contain all typical Gothic elements: the settings are castles, convents, churches, subterranean vaults and caves; the heroines are defenceless against haughty barons; the real solution makers are primarily men; there is a schism between the north and south of Europe; and Protestantism is favoured over Roman Catholicism.

Nonetheless, an exception to some Gothic conventions is her first novel The Castles of Athlin and Dunbayne. It is the closest replica of original romances of all her Gothic novels. It is not about the uncanny that abounds in her later romances, but about the ancient pride (privileges of aristocracy) that clashes with natural nobility and genuine feelings among characters. Thus it represents a romance where the class barrier between nobility and commons is most evident. There is also no mentioning of religion. The most extraordinary fact is that it takes place in the north, in the Scottish Highlands.

To show the progress from medieval romance and to enable the readers to critically approach Gothic romances, the following section systematically enumerates their characteristics from the standpoints of history, literature, architecture, politics, psychology, philosophy and sociology. In the second part, the paper focuses on Radcliffe's first Gothic novel. It analyses the Gothic conventions in it and how males and females react to internal (psychological) and external (actual) crises.

\section{Gothic Romance}

The genre originates from the late Middle Ages (600-700 years ago) and, according to Gail Ashton $(2010,1)$, it is defined as a story about one's origin. It revolves not merely around "a matter of birthright [...], but [also around] a consideration of our place in the wider world with its myths, narratives of history, unstable constructions of class, ethnicity and nationhood, and the impulses and effects of colonization" $(2010,1)$. Thematically, its focal points are "family drama, kinship patterns, the workings out of gender, ideologies of community, leadership, inheritance, on the tension between public and private, time and space" $(2010,1-2)$.

The Gothic novel has its roots in the traditions of romance; however, historically and etymologically speaking, 'Gothic' refers to the German tribe of the Goths, who destroyed classical Rome and the civilised world (Dryden 2003, 24). The name Goth was

taken and used to prop up one side of that set of cultural oppositions by which the Renaissance and its heirs defined and claimed possession of European civilization: Northern versus Southern, Gothic versus Graeco-Roman, Dark Ages versus the Age of Enlightenment, medieval versus modern, barbarity versus civility, superstition versus reason. (Dryden 2003, 24)

Gothic romance is a blend of medieval romance and the French roman, which is a long prose piece of literature. As Ashton explains: 
The development of Gothic romance seems to spring from the social change and its pertaining anxieties: a late 1700s self-made 'man' (mercantile, Protestant) versus an existing feudal system of property and inheritance rights. In literary terms, we recognize a long tradition of Gothic in dark tales of magic, demons, ghosts, secrets, terror and dislocation. (Ashton 2010, 139)

Ashton further asserts that

Gothic romance seems especially attractive to women. Over 50 female authors wrote Gothic-style works between the 1790s and 1820s alone. This flourishing possibly allowed women access to a literary sphere formerly denied to them. Women's pleasure in romance - evidenced by modern sales figures - seemingly confirms it as a 'feminine' genre. (Ashton 2010, 140)

Robert Hume states that Gothic novels thrived between 1764 and 1820 . These are the years when Walpole's The Castle of Otranto and Maturin's Melmoth the Wanderer were published (1969, 282). He sees their distinctly Gothic form as a "shift away from neoclassical ideals of order and reason, toward romantic belief in emotion and imagination" $(1969,282)$. Hume continues that

the literature of the later eighteenth century attempts to rouse the reader's imaginative sympathies; the particular device employed toward this end by the Gothic novel writers is terror, which Burke had stressed as a factor in emotional involvement in his A Philosophical Enquiry into the Origin of our Ideas of the Sublime and Beautiful (1757). (Hume 1969, 282)

Thematically speaking, "Gothic is a style of writing that exhibits the superfluous, transgression and political debates, all of which test cultural limits and boundaries, and trigger ambivalent emotions of curiosity and anxiety by the stories of darkness, desire and power" (Botting 1995, 1). The notions of plot and psychology are, in Gothic writing, therefore closely connected.

Uncertainties about the nature of power, law, society, family and sexuality prevail in Gothic romances. They are connected to wider threats of disintegration of society, which is manifested most forcefully and noticeably in political and social revolution. The decade of the French Revolution was the period when Gothic romances were most popular. (Botting 1995, 2-3).

Gothic was also "a term raised in several political debates, being associated with revolutionary crowds, enlightened extremists and irrational as well as servile conformity to tyrannical and superstitious feudal values" (Botting 1995, 4). The same author explains that

the terrors and horrors of transgression in Gothic writing become a powerful means to reassert the values of society, virtue and propriety: transgression, by crossing the social and aesthetic limits, serves to reinforce or underline their value and necessity, restoring or defining limits. (Botting 1995, 5)

Therefore, from the political point of view, "Gothic tales can be discussed as tropes that label and demonize the otherness and tend to, not question but preserve the status quo. [...] They provide a space in which key elements of the dominant culture become debated [and] affirmed" (Smith and Hughes 2003, 3).

Critics in general agree that Gothic romance is the genre of the fantastic and extravagant, terror, fear of revolution, breaching the boundaries that should not be crossed (like those of 
incest, rebelling against paternal wishes and disturbing the order of the ancient regime) and anti-Catholic attitude. In spite of Radcliffe's and other authors' attempt to show heroines as strong and independent in their avant-garde, private life rebellions, romance in the end reinstates the mainstream (previous) social order. In this respect, we can see Gothic romances as a tool of counter-revolution. On the other hand, Radcliffe is extremely progressive in portraying the (pre)marital relations of her heroines, as they are able to choose their future spouses and dictate the tempo of their relationship's progress. They are also champions of chastity and unhesitant in refusing marriages of convenience. Although criticised by the early critics for laying too much power in her young women's hands and for triggering superfluous emotions, Radcliffe developed a style that used sublimity and ideas of the Enlightenment to successfully pioneer the new idea of Romanticism, and become commercially successful at a time when male authors and their 'real' novels reigned supreme.

\section{Gothic Theory Applied: The Castles of Atblin and Dunbayne}

The Castles of Athlin and Dunbayne is the vaguest of novels as far as the time frame of the story is concerned. There is no specific time given, but, given the chivalric actions of the protagonists and the buildings where they dwell, it can be placed somewhere in the Middle Ages. Castles are tokens of medievalism, serving as fortresses rather than places of luxury and comfort, which were later in history replaced by palaces. It is a highland story, characterized by the feud between the houses from the title of the romance. The Gothic romance opens with the discrepancy between "the most romantic part of the Highland" (Radcliffe 2007, 1) as "the north-east coast of Scotland" (Radcliffe 2007, 1) is described, and the misery of the house of Athlin, caused by Malcolm, Baron of Dunbayne. The former is described as "proud, oppressive, revengeful; still residing in all the pomp of feudal greatness" (Radcliffe 2007, 1). Later, the origin of the feud between the late Earl of Athlin and Baron Malcolm is depicted. It had been Malcolm's "encroachment on the domain of Athlin" (Radcliffe 2007, 1) that resulted in "the animosity which subsisted between the chiefs" (Radcliffe 2007, 1). "Chiefs [were] in charge of clans built on the bonds created by kinship, feuding, feasting, and gifting" (Houston 2008, 91).

In the fights among the clans, "Athlin had generally been victorious" (Radcliffe 2007, 1). Such private mechanisms of justice were not uncommon in late medieval and early modern Scotland, and they had a stabilizing function, since the "Scottish realm's government and judicial system, especially when compared with England at this time, was relatively localized, privatized and informal" (Hyams and Throop 2016, 52-53). In other words, "the justice of feud is essentially a 'private' apparatus flourishing when and where the mechanisms of justice provided by a 'public' governing authority are weak or non-existent" (Hyams and Throop 2016, 51-52).

However, in our romance the feud between the late Earl and the Baron does not end with resolution of the conflict. "Malcolm, whose pride was touched by the defeat of his people; whose ambition was curbed by the authority, and whose greatness was rivalled by the power of the Earl, conceived for him that deadly hatred [...] and he meditated his destruction" (Radcliffe 2007, 1). Here we can see that the Baron's personality traits do not allow him to resolve his personal and military frustration by reconciliation. He goes into scheming and captures the Earl while he is accompanied only by a small party and slays him and his comrades. At this point, Radcliffe, through the omniscient narrator, tells us that the Earl's widow would avenge him if she had an army large enough to do so. As we will see later, Matilda is one of the rare women in Radcliffe's 
romances who would take some action in order to resolve the mortification of herself and her family. However, Matilda has no resources, so she is "constrained to endure in silence her sorrows and her injuries" (Radcliffe 2007, 2).

For an educated reader of the eighteenth century, Matilda resembled another Matilda - Matilda the Empress (1102-1167), of whom Margaret C. Schaus $(2006,551)$ writes in Women and Gender in Medieval Europe. The latter was the daughter of King Henry I of England. As a girl, she was sent to Germany to marry Emperor Henry V. They had no children but she managed to carry out other duties of the Holy Roman Empress. In 1125, when widowed, she returned to England and, after her brother's death, became King Henry's only heir. After her father's death, she failed to reign on her own, as she did not get the support of London barons and due to the resistance of King Stephen's Queen, also named Matilda. "After 1142, she began to fight on behalf of her son Henry's right to succeed Stephen, a goal that was secured in 1152, when Henry was named Stephen's heir. He succeeded two years later" (Schaus 2006, 551). A similar deed was performed by Matilda of Athlin, as she "devoted herself to the education of her children [...] and their growing virtues promised to repay all her tenderness" (Radcliffe 2007, 2). At the beginning of the novel, Matilda's son Osbert is nineteen years old "and his heart, unchilled by the touch of disappointment, glowed with all the warmth of benevolence" (Radcliffe 2007, 2). Through such a description of the young man, Radcliffe suggests that experience and disappointment make one bitter and aggressive. This statement is supported further in the text in the long passage where Radcliffe adopts the Shakespearean "all-the-world's-a-stage" analogy, but she does not apply it to the social roles that humanity plays on the stage of the world. Rather, she mimics William Blake's Songs of Innocence, published in the same year (1789) as The Castles of Athlin and Dunbayne.

Radcliffe meditates upon people's perception of life and the response to life's drama in general and does not distinguish at this point between men and women. Later on, Mary, Osbert's sister, is described as being seventeen years old, but having "the accomplishments of riper years" (Radcliffe 2007, 3). So far, both Osbert and Mary have had no need to face any problems or crises. However, the above offset passage gives us a hint that certain experiences are about to alter the lives of these two inhabitants of Athlin Castle.

Matilda, on the other hand, has grieved for twelve years now, but time has "blunted the keen edge of sorrow. Matilda's grief [has] declined into a gentle and not unpleasing melancholy, which gave a soft and interesting shade to the natural dignity of her character" (Radcliffe 2007, 3). Here, we can observe one of the typical Radcliffean female responses to crisis: passivity. Benevolent female protagonists in Radcliffe's romances are rarely active solution makers. In Matilda's case, in addition to accepting her current situation and status, the passivity and time have to some degree diminished the consequences of her calamities - at least in the psychological sense.

Eventually, Osbert becomes acquainted with the manner of his father's death and "his young heart glowed to avenge the deed" (Radcliffe 2007, 4). Even the late Earl's clan had wanted that, "but oppressed by the generous compassion of the Countess, their murmurs sunk into silence" (Radcliffe 2007, 4). At this point, Matilda has the right to decide on behalf of her children and people since she, with

the early death of [her] husband, leaving young children, [...] became [the sole] guardian of the lands and resources, and, [as] a major fief was involved, [the] regent. Widowhood also added to a [medieval] woman's personal riches since her dower was normally one third of her husband's lands and rents. As well, his death returned to his wife her personal 
power over any inheritance or dowry which she had brought to the marriage; if that had included a county because of lack of male heirs, she as countess legitimately exercised rule and enjoyed its revenues so long as she did not remarry. (Labarge 1997, 104)

People often have a mistaken image of a medieval aristocratic woman. According to Ruth Johnston,

the image we have of the medieval lady is a fairy-tale construction blended with truth. Most upper-class women led difficult lives, although they were surrounded by luxury. Their marriages were often unkind, since they were matched on the basis of land, money, or power. But they lived on a plane above the noise and dirt of the classes below them, and they left behind an impression of magical elegance. Some of this image comes from the romances and troubadour songs. Many romances told the stories of beautiful, refined, intelligent, sweet ladies who won the love of kings and knights and who suffered for this love. While some real ladies led such lives, most did not. (Johnston 2011, 741)

Although Osbert submits to Matilda's wishes not to engage into revenge, his daily activities foreshadow the way he wants to avenge his father, i.e., in battle and in a chivalric manner. Apart from that, Osbert's attracted to poetry and inspired by the scenery of Highlands. Indeed, he is a typical character of the school of thought of Romanticism, and indulges in the sublime, an emotion which exceeds his mother's melancholy in dynamics and fortitude. Edmund Burke defines the sublime

an experience of a power that exceeds the quantifiable and the usable. Encounters with such a power, he observed, are characterized by pain and terror rather than by pleasure and love. For sublime power so transcends the bounds of the finite and the mortal that the individual has the sense of being threatened with obliteration when encountering it. Experience of the sublime is thus marked by a terrifying thrill rather than by pleasurable affection. (Burke qtd. in Day 2011, 183)

The Castle of Athlin and Dunbayne introduces the notion of natural nobility to its readership. However, the notion is in this romance connected with actual nobility, which the readers discover at the end of the novel. Such an example is the seemingly low-born Alleyn, with whom Osbert gets acquainted during one of his wanderings. He is described as a young Highland peasant, who helps him find his own castle when he loses his way. He is also introduced to Alleyn's father. Osbert discovers in his young scout "a dignity of thought, and a course of sentiment similar to his own" (Radcliffe 2007, 6). The young man possesses a form of natural nobility, which attracts the young Earl. When they pass the castle of Dunbayne, Osbert feels uncomfortable and sighs. At the same time, Alleyn comments on Baron Malcolm's bad husbandry over his lands. They lie uncultivated and his people struggle to survive as the yield is insufficient. The Baron is not only inferior in rank in comparison with the Earl of Athlin, but he is also a murderer and fails to do his homework in home economics. Such a characterisation is typical of Radcliffean antagonists who are generally portrayed as ultimate villains. Osbert finds in Alleyn an ally against the overconfident Baron, for the latter says: "There are other clans as ready as your own to avenge the wrongs of the noble Earl of Athlin; the Fitz-Henrys were ever friends to virtue" (Radcliffe 2007, 7). In spite of Alleyn's "glow of conscious dignity" (Radcliffe 2007, 7) and his willingness to assist Osbert in his cause, he is not at this point ready to defy his mother's wishes not to fight. When he sees "the image of his weeping mother [in his] mind" (Radcliffe 2007, 7), he decides to postpone any potential military action. 
Avenging the late lord Athlin, is, however, inevitable. The very next day, after the tournament and Alleyn's success at the tournament - another emblem that he is a natural knight - the young Earl and his clan make a resolution not to rest "till the life of their enemy had paid the debt of justice and of revenge" (Radcliffe 2007, 9). The resolution is not spoken aloud; it is made by the clan crossing their swords with the sword of a man standing next to him. Here again we can observe the real action makers in The Castles of Athlin and Dunbayne - chivalric men who have to wait for several years until Osbert has reached his mental and physical maturity.

The novel deals with male issues as well, both in political and love affairs. This is shown later that day when Osbert and Alleyn feel oppressed by uneasy thought. The former ponders how to verbalize the above-mentioned resolution to his mother Matilda, and the latter has on his mind only "the image of high-born Mary" (Radcliffe 2007, 10) with whom he danced that very evening. Here is the first instance of the clash of social classes in the novel. Not only is Alleyn in love, a fact which he wants to conceal from himself, but he is also of inferior rank - only a peasant - which presents an obstacle to their union. However, he decides to leave his love feelings behind for the time being and leaves "the castle full of gratitude and secret love, to prepare his friends for the approaching war” (Radcliffe 2007, 10). When Matilda gets acquainted with her son's intentions she reacts in a fashion that the majority of Radcliffean benevolent women do: she is "overcome with dreadful sensation, and [sinks] lifeless in her chair" (Radcliffe 2007, 10).

Osbert is not indifferent to this. He is "torn by the most cruel conflict: filial duty, honour, revenge, [command] him to go; filial love, regret, and pity, [entreat] him to stay" (Radcliffe 2007, 10). It is the first real mental crisis he has encountered so far. When the old countess is revived, Osbert sees his sister Mary in "her tears, her sighs, [...] but the silent grief of the Countess [is] still more touching" (Radcliffe 2007, 10-11). He almost resigns from his purpose in order to comfort his mother, who relives the event when she lost her husband. The time has not obliterated her largest scar. Osbert summons the war council, where they decide that Baron Malcolm will be attacked at full force and that it should be a surprise. To achieve that, it will be given out that the assembled army is meant to assist "the Chief of a distant part" (Radcliffe 2007, 11).

The driving force of Alleyn was "the pride of distinguishing himself in the eyes of his mistress" (Radcliffe 2007, 12), and he collected a substantial number of warriors in a short period of time. The assembled army decides that the Alleyn's party "should scale the walls, surprize the centinels [sic], and open the gates to the rest of the clan, which, with the Earl, were to remain without" (Radcliffe 2007, 14). Both parties manage to enter the castle, but there they are outwitted by the defenders - "suddenly the portcullis was dropped and the bridge drawn up" (Radcliffe 2007, 14).

The soul of Alleyn seemed to acquire new vigour from the conflict; he fought like a man panting for honour, the certain of victory; wherever he rushed, conquest flew before him [...]. He, with the Earl, [...] hoped to have satisfied a just revenge, and to have concluded the conflict with the death of the murderer. (Radcliffe 2007, 15)

The law, and the resolution of all Earl's problems is, as can be observed here, in his hands and in those of his helpers - Alleyn; the method to practice it is violence, and the goal of such a practice is to annihilate the enemy and kill them. This was common practice in medieval times.

Carol Lansing and Edward D. English write that 
the medieval [judicial] situation was antithetical to the modern. Then law was plural, overlapping, and predominantly local. Courts were weak or non-existent, laws customary, justice in the hands of venal lords or prelates, or even in the hands of private individuals altogether (feud and revenge). Law was anything but rational, being instead highly ritualized and formal, with modes of proof including torture or ordeal. (Lansing and English 2010, 335)

The above paragraph confirms the thesis that the actions of both the Earl and Alleyn are not based on reason but on emotions, namely vengeance and pride. The next proof can be found in the description of Osbert's feeling at the annual celebration, after the clan members drink in the honour of him: "Osbert understood the signal, and overcome with emotion, every consideration yielded to that of avenging his father" (Radcliffe 2007, 8-9). The attempt to capture and assault Baron Malcolm failed because of the Baron's information about the preparation of war, obtained by the mercenaries that had been spying on Athlin Castle for several years. Many assaulters were killed, and those who survived carried the news that Earl and Alleyn had been captured as prisoners of war to Countess Matilda (Radcliffe 2007, 15-16). She cannot stay strong under such a calamity. "She was attacked with a violent illness, which had nearly terminated her sorrows and her life" (Radcliffe 2007, 16). Her daughter Mary nurses her, and, although she "felt all the horrors of the late event (Radcliffe 2007, 16), she "almost forgot [her] own distress in the remembrance of her mother's [...]. She had also a strong degree of pity for the fate of the brave young Highlander who had assisted” (Radcliffe 2007, 17).

In the castle of Dunbayne, Baron Malcolm welcomes the young Earl with words of sarcasm, a sign of intelligence, but also an outward emblem of his depravity: "I am [sic] come [...] to welcome the Earl of Athlin to my castle; and to shew that I can receive my friends with the hospitality they deserve; but I am yet undetermined what kind of festival I shall bestow on his arrival" (Radcliffe 2007, 19). The Baron is surely not a friend of Osbert's, nor does he desire to throw him a party. The 'festival' is, in this case, a euphemism for torture. The contradictory feelings of "furious indignation and tender pity which the glowing image of his father could excite" (Radcliffe 2007, 20) put Osbert into the state of "perfect misery" (Radcliffe 2007, 20). When he is almost driven to madness and to committing suicide with "a short dagger, which he concealed under his vest" (Radcliffe 2007, 20), his spirit is lifted by music played on the lute and "by a voice so enchantingly tender and melodious that the sounds fell on the heart of Osbert in balmy comfort" (Radcliffe 2007, 20). Above, we can see an instance when Osbert nearly loses his will to live, and his sanity is preserved by the means of the external medium. The latter response is typical of Radcliffe's Romantic protagonists.

The romance demonstrates both the constructive and unconstructive behaviour on the part of benevolent characters. While the young count is being imprisoned, "the castle of Athlin, and its neighbourhood, [is] overwhelmed with distress" (Radcliffe 2007, 20). This is an unconstructive response to crisis. The countess, Osbert's mother, reacts reasonably and sends a substantial ransom to the baron "for the restoration of her son, and other prisoners" (Radcliffe 2007, 21). In spite of the wealth offered to him, the baron's "revenge subdues his avarice," and he rejects the ransom with contempt. This is not the only conflict the baron bears in his heart; he threw an eye on beautiful Mary once and this view "raised a passion in his soul, which the turbulence of his character would not suffer to be extinguished" (Radcliffe 2007, 21). By having her brother in his possession, he now has the means to obtain Mary. A small number of clan members want to rescue the count, which revives the countess, but there is another misfortune: Mary's 
health notably declines. "She was silent and pensive; her tender frame was too susceptible of the sufferings of her mind; and these sufferings were heightened by concealment" (Radcliffe 2007, 21). What Mary experiences is a psychosomatic response, and since she does not verbalise her grief, the physical reaction grows even stronger. As a remedy, "she was prescribed amusement and gentle exercise, as best restoratives of peace and health" (Radcliffe 2007, 21).

When acting according to the given prescription, she is captured by three banditti and taken towards a cavern, where she loses "all signs of existence" (Radcliffe 2007, 22), i.e., consciousness. She is rescued by Alleyn "who was watching with the most trembling anxiety her return to life, and whose eyes, on seeing her revive, swam in joy and tenderness" (Radcliffe 2007, 22-23). She is accompanied to the castle of Athlin, where Alleyn conveys his story of how he was imprisoned and escaped the baron. "After having lain some weeks in the horrible dungeon allotted him, his mind involved in the gloom of despair, and filled him momentary expectation of death, desperation furnished him with invention, and he had concerted the [...] plan to escape" (Radcliffe 2007, 24). Alleyn yet again proves to be an active participant in solving problems, although at first he experiences severe melancholy. He is rational and systematic in his quest to find the way out of the castle of Dunbayne. This is evident in his careful observation of the guard's behaviour regarding the pavement near the entrance of his dungeon cell: "the guard was constant in examining it by striking that spot, and treading more firmly on it; and this he endeavoured to do without being observed" (Radcliffe 2007, 24).

The romance also gives its readers an instruction on perseverance and endurance, notions which are especially hallmarks of Alleyn. Alleyn, ever resourceful, removes the pavement of the spot, digs into it and finds a trap. However, he is fatigued at that time and unsure whether he will be able to come through the door and overcome all the other obstacles that may follow. That is why he decides to place the pavement in the exact spot it was before. He fails to do so and "his mind and body [are] [...] overcome, and he [throws] himself on the ground in an agony and despair." Here we can observe that mind and reason, no matter how determined one is, can temporarily fail benevolent characters. Nonetheless, they quickly re-establish their original composure and continue to follow their aim. Therefore, when Alleyn is revived, he opens the trap door and enters the vault. After wandering for a substantial amount of time, he senses "the gentle undulation of the air upon his face [...] which [gives] him strength; and the means of escape, which now [seems] presented to him, [renews] his courage" (Radcliffe 2007, 24-25). Here one can see how nature and its phenomena can influence a human being, which is a Romantic notion, proving that Gothic fiction is actually a subsection of Romanticism.

The benevolent characters in Gothic fiction, as presented above, often react extremely emotionally, or at least the Gothic authors use hyperbole to describe characters' emotional response, hence "inexpressible anguish." When Alleyn wants to pursue his discovery of the castle vaults and from there "leap the wall, and cross the ditch" (Radcliffe 2007, 26), he is discovered by an armoured guard who loses his sword in the fight with Alleyn. When the former pleads for mercy, Alleyn decides not to kill the guard due to his compassionate nature and for practical reasons: if he killed him, the other guards would enter the vault. Here we can observe more characteristics of positive Gothic characters, namely humility, compassion and rational/pragmatic thinking. The guard wanders back to his comrades and meets Malcolm, who orders Alleyn to be chained. When the latter boldly stands up to Baron Malcolm and threatens the guard to take his life in case of another escape of the prisoner, the guard, feeling resentful towards his master and grateful towards merciful Alleyn, starts wavering between obedience (saving Alleyn life) and disobedience (escaping his lord). 
When the latter offers a reward should he save him, the guard refuses to accept it, saying that it is enough for him to save a fellow creature from destruction (Radcliffe 2007, 28-29). "These words overpowered Alleyn, and tears of gratitude swelled in his eyes" (Radcliffe 2007, 29). The guard's response has a didactic value: if one helps a fellow human being, one gets in return their gratitude and, consequently, can justly expect a positive outcome from temporary misery.

Being sentimental and grateful are therefore the two personality traits exhibited by positive characters in Gothic romances. Alleyn is given a knife and he successfully cuts all around the lock, unfastens the chain, leaves the cell, reaches the trap door and with difficulty separates the bolts, whereupon the open door enables him to see the vaults. It is evening now, and he returns to his dungeon and rests on the floor. When somebody opens his jail, Alleyn discovers that it is not Edric, the sentinel who was supposed to help him escape at midnight. After he leaves, Alleyn cannot endure the stress any longer, so he "sunk[s] down in a state of torpidity" (Radcliffe 2007, 30). When he recovers, he again finds himself in silence, darkness and melancholy. Nevertheless, he disregards the doubt in his soldier's fidelity. Here, Radcliffe adds a remark of the reminiscent narrator: "We naturally recoil from painful sensations, and it is one of most exquisite tortures of a noble mind, to doubt the sincerity of those in whom it has confided" (Radcliffe 2007, 30), thus foretelling that Alleyn is - against all odds - of noble birth. When Alleyn concludes that Edric was sanctioned because of his generosity, he forgets the situation in which he is now, which denotes another feature of Radcliffe's protagonists, i.e., compassion and sincere care for others. Since Radcliffe's Gothicism is of a psychological kind, the fears and terrors in her romances are primarily oppression upon the mind, caused either by external circumstance or by false interpretations and assumptions. This is manifested in Alleyn's delayed reaction to the noise of approaching persons:

His senses had been so stunned by the appearance of the stranger, and his mind so occupied with a feeling of despair, as to exclude every idea of escape; and in the energy of his sufferings he had forgot [sic] this last resource. It now flashed like lightning upon his mind; he sprung to the trap door. (Radcliffe 2007, 31)

After all the psychological turmoil, Edric arrives with his fellow guard, whose appearance scared Alleyn before, and the former tells Alleyn that his comrade, too, cannot tolerate Baron Malcolm's oppression and plans to escape with them (Radcliffe 2007, 31). One of the characteristics of Radcliffe's Gothic romances is that the fear stimuli of protagonists are, after suspense, rationally explained. This makes her novels psychology textbooks that implicitly teach the readership to act according to Aristotelian Golden Means, something that the eighteenth century with its Enlightenment movement and Neo-Classicism strived to act according to. The above example therefore shows how Alleyn was overreacting, at least in his mind. Because of this, he hardly acted towards his salvation. Such reactions are common for benevolent characters in Radcliffe's novel, especially female ones.

The Castles of Athlin and Dunbayne is also unique in a sense that it does not attempt to suggest there are any supernatural phenomena at work. The closest contact of any characters with the uncanny is when Alleyn and the rebellious soldiers wander in the underground vaults. There their lamp is extinguished and they have to continue in darkness. "Their feelings may be more easily imagined than described" (Radcliffe 2007, 32). However, this is not all. Alleyn accidentally strikes up against broken armour and discovers the dead body of a man next to it. Touching the corpse makes him overwhelmed - "every nerve thrilled with horror at the touch" (Radcliffe 2007, 32). Moreover, when some light appeared, "they could distinguish the figures of men $[\ldots]$ and $[\ldots]$ they doubted not but the men $[\ldots]$ were murderers; that they belonged to the 
Baron; and were in search of some fugitives from the castle" (Radcliffe 2007, 33). They ascend to a higher level of vaults and rest for a while in silence and total darkness. When they try to descend towards the exit of the vaults, they spot a light again where the dead body lies. "They [stand] petrified with despair" (Radcliffe 2007, 33). The light luckily passes on and shows them their position. They safely reach the bottom of the staircase and the deliverance is near, when they encounter four men with a lamp and swords drawn and pointed towards the party. When Alleyn shouts: "We will die hardly[!]," their weapons drop and Alleyn notices that three of them are his comrades and the fourth is Edric's fellow soldier. "They [quit] the cave together" (34). The finding of the corpse is, as it is common for Radcliffe, explained, thus eliminating every trace of the supernatural that we can, for instance, find in Walpole's The Castle of Otranto: "They concluded, that the body which they passed in the avenue, was some person who had perished either by hunger or by sword in those subterranean labyrinths" (Radcliffe 2007, 34). This kind of rationalism, also called "explained Gothicism," is sometimes criticised as the element that destroys Gothic suspense and its crucial fibre - the belief in the supernatural. Yet, it is a hallmark of Radcliffean Gothicism which separates her from other, especially male, Gothic writers.

The novel also introduces the notion of ruffians/banditti - a common phenomenon in Gothic romances. They were intimidating, a party not to be dealt with and better to be avoided, as they did not follow any rules of conduct (with the exception of pirates). They were merely mercenaries who answered to money alone. Mary encounters them and is lucky to be saved by one of Malcolm's former soldiers (Edric) and Alleyn, who are told by Matilda's wounded servants that Mary was abducted by some ruffians. They catch up with the bandits at the entrance of a cavern "whose frightful aspect had chilled the heart of Mary with a temporary death" (Radcliffe 2007, 35), and save her. Alleyn is struck with horror when he sees lifeless Mary, but when she revives "joy once more illuminate[s] his soul" (Radcliffe 2007, 35). "A temporary death" is a hyperbole - an exaggerated phrase - meaning to lose your consciousness. Hyperboles are a common figure of speech in Radcliffean romances and go hand in hand with characters' turbulent emotional responses.

Here, the long escape story of Alleyn finishes and Mary once again faints as the result of "all the vicissitudes of his situation" (Radcliffe 2007, 35). Here the verbal, emotional and physical reactions - a common trinity in Radcliffe's romances - coincide: Alleyn's narrative causes Mary's emotions to become overwhelming, which results in fainting (bodily response). Mary's interest in Alleyn's adventure gives "Alleyn mixed delight of hope and fear [...] for the first time he dared to acknowledge to his own heart that he loved, and that heart for the first time thrilled with the hope of being loved again" (Radcliffe 2007, 36). At this stage, Alleyn remains a passive lover, but again, he does not need to be active right now as he receives a grateful response from Countess Matilda "and from Mary a blush which spoke more than her tongue could utter" (Radcliffe 2007, 36). This party together discovers that the scheme of kidnapping Mary was a deed of Malcolm, who had ordered it before the Earl fell in his hands and forgot to cancel it. We can see that villains are especially active in Gothic romances, although they do not often perform evil acts on their own - they most commonly hire mercenaries or make use of their servants.

When Alleyn expresses his design to join his friends and himself with the clan, the Countess gives him leadership over her army (Radcliffe 2007, 37), which is one of the rare occasions in Radcliffe's novel where women act powerfully and proactively. Mary is at first hopeful as she anticipates her brother's return, but then becomes fearful that Alleyn may have been slain. The information, given to the readers by the omniscient narrator, is crucial when discussing 
the class conflict in this novel: Mary admires Alleyn's "brave and manly virtues [...] [that] the insignificance of the peasant [is] lost in the nobility of the character" (Radcliffe 2007, 37). Her attitude shows the dichotomy of her mind and heart, her upbringing and her genuine feelings, and the ideological conflict that any aristocratic lady in the Middle Ages would have had, i.e., how a noblewoman can love a man of low birth. It also predicts Alleyn's noble origin, for in the Middle Ages, in the aristocracy, "nobility of blood could justify itself through nobility of mind and soul. External refinements and physical beauty were hollow unless they were visible signs of inner worth. The Beautiful was the outer clothing of the Good" (Jaeger 1999, 36-37).

The spiritual and psychological states of the Earl have, in the meanwhile, somewhat improved. He has trained himself through "habitual contemplation" (Jaeger 1999, 39) not to look upon the worst with fear, but rather with "serenity" (Jaeger 1999, 39). From this, we can observe that male protagonists are not only active action providers from the outside, but also from the inside. They are able to effectively control raging and destructive thoughts. One of the methods they use to do that is contemplation, otherwise a hallmark of monastic orders. Another one is distraction, which we can detect in the Earl's "observing the manners and customs of the birds of prey" (Jaeger 1999, 39). He parallels their "rapacity [...] to the habits of men" (Jaeger 1999, 39). This comparison demonstrates the rich spiritual and intellectual life of benevolent and upper class characters that pertains to both men and women in Radcliffe's romances. However, this mental activity, i.e., contemplation, is reserved for the aristocracy.

Music and poems play an important part in Radcliffe's romances: they function as a medium of the oppressed benevolent character through which they express their aspirations and tell their life story. In The Castles of Athlin and Dunbayne, there is the song "When first vernal morn of life," sung by a young lady who is imprisoned together with her mother in the same castle as Osbert. The song tells the story of a young person, whose heart is "with filial fondness fraught" (Radcliffe 2007, 40, line 10),

But o! the cruel quick reverse!

Fate all I loved involv'd;

Pale Grief Hope's trembling rays dispers'd,

And Fancy's dreams dissolv'd. (40, lines 13-16)

'Froght', which in Scottish English stands for a cargo, brings a subtle sentiment of Scotland in this personal tale of disillusionment. The stanza cited above is the last stanza of the song/poem and foretells, together with line 10, what Osbert, the Earl, will learn some time later. What he learns is that Laura, the young lady who has been imprisoned with his mother for fifteen years in the castle of Dunbayne, is the daughter of the late Baron, "who, in the pride of youth, [...] was killed by a fall from his horse, which he received in hunting" (Radcliffe 2007, 76). The current Baron did not only take over the paternal estates, which rightfully belonged to him as the former Baron had no son, but also his brother's personal property and estates in Switzerland, which were given to his wife and daughter. The argument for doing so is explained by the Baron thus: "The frequent and ill-timed generosities of my brother have diminished the value of the lands which are mine by inheritance; and I have therefore an indispensable right to repay myself from those estates which he acquired with you" (Radcliffe 2007, 77).

From the above paragraph, another characteristic of malevolent characters is apparent, and that is greed. However, the Baron is not completely immune to love, no matter how selfish it may 
be. In spite of his rage directed towards the Earl for Alleyn's escape, he decides not to execute him because of his love to the latter's sister Mary. His plan is to trade Osbert's life for Mary's hand (Radcliffe 2007, 42-43). No matter how tortured his mind, Osbert places his hope in the letter which a compassionate soldier has taken to Countess Matilda. Indeed, the result is that the remainder of the clan led by Alleyn approaches the castle of Dunbayne. The Baron Malcolm declares that attack on the castle means the death of their chief and that the ransom for his freedom is to be none other than Mary becoming his wife.

The situation of Alleyn was highly pitiable; all the firm virtues of his soul were called upon to support it. He was commissioned on an embassy, the alternate conditions of which would bring misery on the woman he adored, or death to the friend whom he loved. (Radcliffe 2007, 50-51)

The difference between Malcolm's and Alleyn's actions regarding love can be found by answering the following questions, implicitly asked by Lacan: "How do we express desire and act ethically at the same time? [...] If our desires are animal and without consideration of moral or ethical laws, dictates, or maxims, then how can they exist simultaneously with our ethical being in the world?" (Labbie 2006, 73). The answer, at least in the spectrum of a medieval mind, is courtly love and chivalry. By making desire institutionalized and sanctified, it became valid also in a moral and ethical sense.

Countess Matilda and her daughter Mary are both in great distress as they have to decide upon the fate of Osbert and Mary herself. First, Mary agrees to marry the Baron, but then the answer to the question whether she is to be married to the Baron is postponed and is to be given in two weeks' time. In the meantime, Alleyn decides to find out if the Earl has been relocated (Radcliffe 2007, 51-58). The above instance of women's agency is one of the few in Radcliffe's romances. Mary is willing to give herself into marriage with her family's foe to save the life of her brother and to free him. To save the Earl, no military intervention of the clan is needed, as one of the guards, Edmund, helps him escape and reunite with his soldiers, Alleyn and later with his family. Athlin is once again a place of joy. The joy of Alleyn is soon disturbed by a sophisticated visitor from Switzerland, Count de Santmorin, who shows interest in Mary. It turns out - and such twists are common in Radcliffe's Gothic romances - that he was driven to Scotland by the news that his relative, who happens to be Baroness Malcolm, is dead.

Mary is reluctant to accept the Swiss Count's offer, despite the support he has in the Countess. Her heart belongs to Alleyn. Osbert reminds her of her duty as a woman and a member of higher class: "You do well remember the dignity of your sex and of your rank; though I must lament with you that worth like Alleyn is not empowered by fortune to take its standard with nobility" (Radcliffe 2007, 104). Taking into account Alleyn's merits, he would give his sister's hand to him if only the former were wealthy enough. He would even forget that Alleyn is not an aristocrat.

In the example above we can see that Gothic romances are a genre that enforces the Middle Age's "natural" order - the divine right of aristocracy to rule over their subjects - and to make a clear division between the servants and their masters. The novel ends with an epic battle between good (Osbert's and the Count's soldiers) and evil (Baron Malcolm's clan), in which Malcolm is mortally wounded. Nevertheless, before dying, he says to the Baroness: "I have injured you, Madam, I fear beyond reparation. In these last few moments let me endeavour to relieve my conscience by discovering to you my guilt and my remorse" (Radcliffe 2007, 109). This response is typical of Radcliffean villains: they repent only before they die. The "guilt" he has in mind is 
the fact that he concealed from her that he had banished from the castle her son Philip, who she thought had died in her absence. The lost son happens to be Alleyn, who according to his hereditary right becomes Baron Philip (this was his real name all the time) Malcolm of the castle of Dunbayne. With his newly obtained social rank, he is now able to marry his love, Mary. The Earl also marries - he takes the Baroness's daughter Laura, which results in double-connection of the families of Athlin and Dunbayne. The social order is thus kept intact and any subversion is out of sight. The latter was of utmost importance as the first edition of the novel was published in 1789, the year of the start of French Revolution, and the second in 1793, when the Revolution was at its peak. The role of Gothic romances was to maintain and cherish peace, freedom and order that only the establishment can give.

The novel is also unique as it has no anti-Catholic connotation and it, surprisingly, takes place as far north as no other original Gothic novel had ever done. With it, Radcliffe does not assert that Protestantism prevails over Catholicism, and that North is far better than South, but that, on the one hand, winds of change are inevitable, and on the other, that changes must occur within the scope of the Enlightenment, while preserving the establishment. The romance stresses the importance of natural nobility, expressed by Alleyn and admired by Mary, but also tends to keep the ancient pride and economic shrewdness possessed by Osbert.

\section{Conclusion}

The paper has presented various characteristics of the new romance, i.e., Gothic romance. It has proven that The Castles of Athlin and Dunbayne reinforces the conventions of the old (medieval) order rather than challenges them. This is especially shown when Osbert is reluctant to give hand of his sister to non-aristocratic and not-of-substantial-means Alleyn. Such an approach in writing is understandable as revolution was starting in nearby France and the novel thus had its role to show the benefits of stability.

The paper also emphasises the atypical features of The Castles of Athlin and Dunbayne in terms of its setting (north), the absence of religious connotation (no anti-Catholicism) and uncanny phenomena (the appearance of a found corpse is rationally explained), as well as the power vested in women (owing land, freedom to choose their spouse within their social rank).

As Radcliffe's romances present an important vehicle to Romanticism and are faithful representatives of the Enlightenment movement, they should be studied as a part of the English literature curriculum. They should also be included in broader literary studies and enumerated in philosophical discourses and treatises due to their solid arguments in favour of the rationalism on which the contemporary society is based. My call is also to the translators of literature, as none of Radcliffe's novels has been translated into Slovenian.

\section{References}

Ashton, Gail. 2010. Medieval English Romance in Context. London: Continuum.

Botting, Fred. 1995. Gothic. Florence, KY: Routledge.

Day, Aidan. 2011. Romanticism. Florence, KY: Routledge.

Dryden, Linda. 2003. Modern Gothic and Literary Doubles: Stevenson, Wilde and Wells. Gordonsville, VA: Palgrave Macmillan. 
Houston, Rab. 2008. Scotland. Oxford: Oxford University Press.

Hume, Robert D. 1969. "Gothic versus Romantic: A Revaluation of the Gothic.” PMLA 84 (2): 282-90.

Hyams, Paul R., and Throop, Susanna A. 2016. Vengeance in the Middle Ages. Farnham, Surrey: Routledge.

Johnston, Ruth A. 2011. All Things Medieval: An Encyclopedia of the Medieval World. Westport, CT: Greenwood.

Jaeger, Stephen. 1999. Ennobling Love: In Search of a Lost Sensibility. Philadelphia, PA: University of Pennsylvania Press.

Labarge, Margaret. 1997. Medieval Miscellany. Montreal: McGill-Queen’s University Press.

Labbie, Erin Felicia. 2006. Lacan's Medievalism. Minneapolis, MN: University of Minnesota Press.

Lansing, Carol, and English, Edward D. 2010. Companion to the Medieval World (1). Hoboken, NJ: WileyBlackwell.

Radcliffe, Ann Ward. 2007. The Castles of Anthlin and Dunbanye. Leipzig: RHYW.

Schaus, Margaret C. 2006. Women and Gender in Medieval Europe. Florence, NC: Routledge.

Smith, Andrew, and Hughes, William, eds. 2003. Empire and the Gothic: The Politics of Genre. Gordonsville, VA: Palgrave Macmillan. 